\title{
Synopsis on the Taxonomy of the Genus Xanthomonas
}

\author{
Luc Vauterin, Jan Rademaker, and Jean Swings
}

First author: Applied Maths, Derbystraat 331, 9051 Gent, Belgium, and Laboratorium voor Microbiologie, Universiteit Gent, Ledeganckstraat 35, B-9000 Gent, Belgium; second author: The Netherlands Culture Collection of Bacteria (NCCB), Utrecht University, PO Box 80056, 3508 TB Utrecht, the Netherlands; and third author: Laboratorium voor Microbiologie and BCCM/LMG Bacteria Collection, Universiteit Gent, Ledeganckstraat 35, B-9000 Gent, Belgium.

Accepted for publication 24 March 2000.

\begin{abstract}
Vauterin, L., Rademaker, J., and Swings, J. 2000. Synopsis on the taxonomy of the genus Xanthomonas. Phytopathology 90:677-682.

The genus Xanthomonas exhibits a high phytopathogenic diversity in contrast to a phenotypic uniformity, which has hampered the genesis of a stable classification for a long time. In past decades, a large number of Xanthomonas strains have been characterized by a variety of phenotypic and genotypic methods in a multitude of studies. Extensive DNA hybridi-

The genus Xanthomonas is remarkable by its phytopathogenic diversity and its contrasting phenotypic uniformity. Therefore, and due to its economic importance, the genus has been the subject of large-scale taxonomic studies and numerous discussions on the classification and nomenclature of its members. In response to a proposal for rejection of a number of Xanthomonas species (29), we would like to provide a review of all the work that has led to the current classification of the genus and a synopsis of recent largescale genomic studies that support the classification.
\end{abstract}

ABSTRACT zation studies and repetitive sequence-based polymerase chain reaction and amplified fragment length polymorphism genomic fingerprinting have clearly revealed the genomic diversity and relationships within the genus. A review of the current classification of the genus Xanthomonas based on the synopsis of these studies is given here.

Additional keywords: BOX-PCR, DNA homology, ERIC-PCR, pathovar, REP-PCR

\section{LIMITATIONS OF A PATHOVAR CLASSIFICATION}

Originally, each variant of the genus Xanthomonas showing a different host range or producing different disease symptoms was classified as a separate species. This practice, described as the "new host-new species" concept (35), led to a complex genus, finally containing more than 100 species. However, the phenotypic homogeneity of the genus $(3,5,38)$, and also the fact that insufficient information was available about the actual phytopathogenic specialization of the taxa, was the major motive of Dye and Lelliott (6) for merging almost all Xanthomonas species into the single species $X$. campestris. Later, Young et al. (51) proposed reclassifying the former nomenspecies (i.e., species only distinguished by their name) into pathovars. This special purpose classification was adopted as a provisional solution until a classification would be established based on more generally accepted principles. Currently, more than 140 pathovars have been defined within the genus Xanthomonas $(1,8)$.

Apart from the fact that pathovars are defined by one single feature, i.e., pathogenicity, and thus have no place in a modern taxonomic environment (43), this system might have represented a useful convenience if there were not three major practical problems with it. (i) In most cases, the host range of strains of a particular pathovar is not known, as no extensive host range studies, includ-

Corresponding author: L. Vauterin

E-mail address: luc_vauterin@applied-maths.com

Publication no. P-2000-0526-010

(C) 2000 The American Phytopathological Society ing numerous cross-inoculations, have ever been performed or at least published. (ii) In an early DNA hybridization study, Murata and Starr (18) reported that there is significant heterogeneity within a number of pathovars, at that time nomenspecies, at the genomic level. Later, this finding was confirmed and extended in numerous taxonomic studies on the genus Xanthomonas $(2,10,20,21,23,28,37$, $43,44,46,47)$. (iii) Nonpathogenic xanthomonads, which are isolated from healthy as well as diseased plants, cannot be classified in a pathovar system. Schroth and Hildebrand (31) were among the first to discuss the shortcomings of a pathovar system in the light of general taxonomy and suggested that a taxonomic scheme for plant-pathogenic bacteria should be based on DNA hybridization matrices.

\section{REEXAMINATION OF THE CLASSIFICATION OF THE GENUS XANTHOMONAS}

To sort out the relationships between the many pathovars and species, a series of studies on the taxonomy of the genus Xanthomonas has been undertaken during the last decade. These studies have mainly addressed the species delineation within the genus. Rather than extending classical phenotypic comparisons by testing individual biochemical and physiological features (38), analytical fingerprinting techniques such as electrophoresis of whole-cell proteins (42) and gas-chromatographic analysis of cellular fatty acids (50) have been applied. The idea of this approach was to analyze a large number of isolates (more than 1,000) from diverse origins using these fast, yet sensitive, fingerprint techniques and then select a more restricted number of representative strains for further genomic study by DNA hybridization. This approach combines the benefits of (i) analyzing large numbers of strains, which is necessary to obtain a representative picture about the biological diversity of the organisms; (ii) overcoming restrictions and errors inherent to a single typing method, by comparing more than one fingerprint technique; and (iii) establishing genomic relationships between the obtained groupings by hybridizing DNA between selected and representative strains.

Results on protein electrophoresis patterns (41) and quantitative comparison of cellular fatty acid contents $(36,50)$ have shown that the $X$. campestris pathovars are phenotypically much more het- 
erogeneous than previously documented. A large number of clusters could be found using each technique, and in some cases, pathovars from related hosts such as members of the plant families Fabaceae, Poaceae, and Brassicaceae seemed to be related to each other (40). Other pathovars appeared to consist of two or more unrelated groups, e.g., $X$. campestris pv. vesicatoria, $X$. campestris pv. poinsettiicola, and X. campestris pv. Dieffenbachiae. Many of the groupings recovered were similar using the two approaches, although significant discrepancies between the results were also found.

\section{THE CURRENT XANTHOMONAS CLASSIFICATION}

In complex genera, in which phenotypic features either yield no discrimination or are, in part, contradictory, genomic DNA hybridization is used as the standard criterion for the delineation of species $(31,43)$. Likewise, the decisive information for members of the genus Xanthomonas came from DNA homology measurements determined by DNA hybridization among 183 xanthomonad strains, selected from both the protein and fatty acid groupings, (39) complemented with several additional strains that also have been hybridized in other studies $(10,20)$. The resultant DNA homology matrix allowed the distinction of 20 genomic groups (39). The data affirmed four groups that were existing species, $X$. albilineans, $X$. fragariae, $X$. populi, and $X$. oryzae, whereas 16 DNA homology groups were new and not consistent with the existing pathovar classification. The latter 16 genomic groups were consequently described as new species (39). The complex rearrangements resulting from the DNA homology relationships within the genus Xanthomonas are schematically represented in Figure 1. In general, DNA homology values between the different genomic groups were below $40 \%$, whereas internal DNA homology values typically were higher than $80 \%$ (39). This discontinuity is a strong argument in favor of the existence of discrete taxa within the genus Xanthomonas and justifies the proposed reclassification into species. Whereas no reciprocal tests were performed in the DNA hybridization study, over 700 assays were performed two to eight times, which led to an overall error of less than $6 \%$.

The strains were selected based on extensive studies of fatty acid methyl ester profiles from over 1,200 strains $(48,50)$ and of wholecell protein profiles from over 1,000 strains (41). Additionally, Biolog GN Microplate (Biolog Inc., Hayward, CA) profiles obtained from 255 strains (39), as well as discriminatory nutritional tests (9), were used to describe the new species phenotypically.

Contrary to what Schaad et al. seem to suggest in their Letter to the Editor (29), there are no particular rules for proposing nomenclatural changes of plant-pathogenic bacteria. The only two mandatory issues bacteriologists need to take into account with respect to nomenclature are the Approved Lists of Bacterial Names (32) and the International Code of Nomenclature (13). The Code has been followed in the reclassification of the genus Xanthomonas and, specifically, the two following important rules were adhered to. (i) When a species is divided into two or more species, the specific epithet of the original species must be retained for one of the taxa into which the species is divided. The specific epithet must be retained for the species which includes the type strain (Rules $40 \mathrm{a}$ and 40b). (ii) When two or more taxa of the same rank are united, then the name of the taxon under which they are united (and, therefore, the type of the taxon) is chosen by the date of publication (Rule 38).

Most of the reclassifications by Vauterin et al. (39) were emendations from $X$. campestris, and the name $X$. campestris was reserved for the taxon that contains the type strain of that species.

In the cases of cassavae, cucurbitae, pisi, a part of vesicatoria (containing the pathovar reference strain), hyacinthi, translucens, melonis, and theicola, the species name was based upon the pathovar name, since they consist of only one homogeneous pathogenic group and the name is not misleading or confusing in terms of suggested host pathogenicity (vesicatoria, translucens). The $X$. campestris pvs. poinsettiicola and vasculorum and the group of pathovars constituting $X$. arboricola, $X$. hortorum, and X. holcicola were proposed as new names, since reuse in the naming of new taxa cannot be recommended if such reuse is likely to result in confusion due to previous or continuing use of the name as synonym, a strain designation, or for other reasons (32).

In the case of DNA homology group 9, however, 27 pathovars fell together with the existing and validly published species $X$. axonopodis and, hence, were reclassified as $X$. axonopodis in accordance with the rules of the Code and the Approved List.

When Vauterin et al. (39) proposed their new species, they took care to incorporate the existing pathovar system as reasonably as possible within the real taxonomic structure of the genus, based on genomic relatedness, by describing all known pathovars within the new species. In those cases in which an existing pathovar appears to be composed of two distinct genomic groups (e.g., vesicatoria, vasculorum, poinsettiicola, and dieffenbachiae), initial confusion may occur with respect to existing quarantine regulations. However, one cannot disregard true relationships between bacteria, and it is our opinion that, in the long run, regulatory officials, seed companies, and scientists will benefit from the knowledge of the true taxonomic structure of the bacteria they are working with.

\section{PHYLOGENY OF THE GENUS XANTHOMONAS}

The efficacy of $16 \mathrm{~S}$ ribosomal DNA sequence analysis resides at a low phylogenetic or taxonomic level of resolution, which is valuable to the classification of bacteria from the genus to even the kingdom level but is insufficient to classify members of the genus Xanthomonas at the subspecies level (7). Analysis of 16S ribosomal DNA sequences of members of the genus Xanthomonas has shown that the genus has three phylogenetic lineages, the first including X. arboricola, X. axonopodis, X. bromi, X. campestris, X. cassavae, $X$. cucurbitae, $X$. codiaei, $X$. fragariae, $X$. hortorum, $X$. melonis, $X$. oryzae, X. pisi, X. populi, X. vasicola, and X. vesicatoria; the second including $X$. albilineans, $X$. hyacinthi, $X$. theicola, and $X$. translucens; and the third consisting of only $X$. sacchari (7).

\section{PATHOGENIC AND GENOMIC DIVERSITY WITHIN THE GENUS XANTHOMONAS}

The apparent contradiction between pathotype and real genomic diversity in the genus Xanthomonas becomes particularly true when the genomic groups (now species) are examined more closely (Fig. 1). A number of examples can be found of former pathovars that fall unexpectedly into two or more species. These include pv. "vesicatoria" (two groups [33,43]), pv. "poinsettiicola" (three groups), and pv. "dieffenbachiae" (two groups). Other pathovars that could not be related on the basis of phytopathogenic specialization form one genomic group, e.g., the pvs. pelargonii (from the genera Pelargonium and Geranium), vitians (from Lactuca spp.), and hederae (from Hedera helix), associated with different hosts and diseases but together forming the new species X. hortorum. Another example is given by the pvs. corylina, juglandis, and pruni, now classified in the species $X$. arboricola. It has been suggested that these pathogens, infecting hazelnut, walnut, and prune, respectively, could have originated from a common xanthomonad that was able to infect and colonize trees in the temperate regions (40). Lee et al. (14) found the members of this species to be distinguishable from other xanthomonads by their ability to metabolize quinate.

The current classification of the genus Xanthomonas (39) is based upon the pathogenic subpopulation of the genus. The real diversity of the plant-pathogenic members of the genus is probably even greater than observed up to now. Some more strains will obviously fit within known species, but others may form new entities or affect existing groups. The situation is becoming even more complex 
Before reclassification

After reclassification

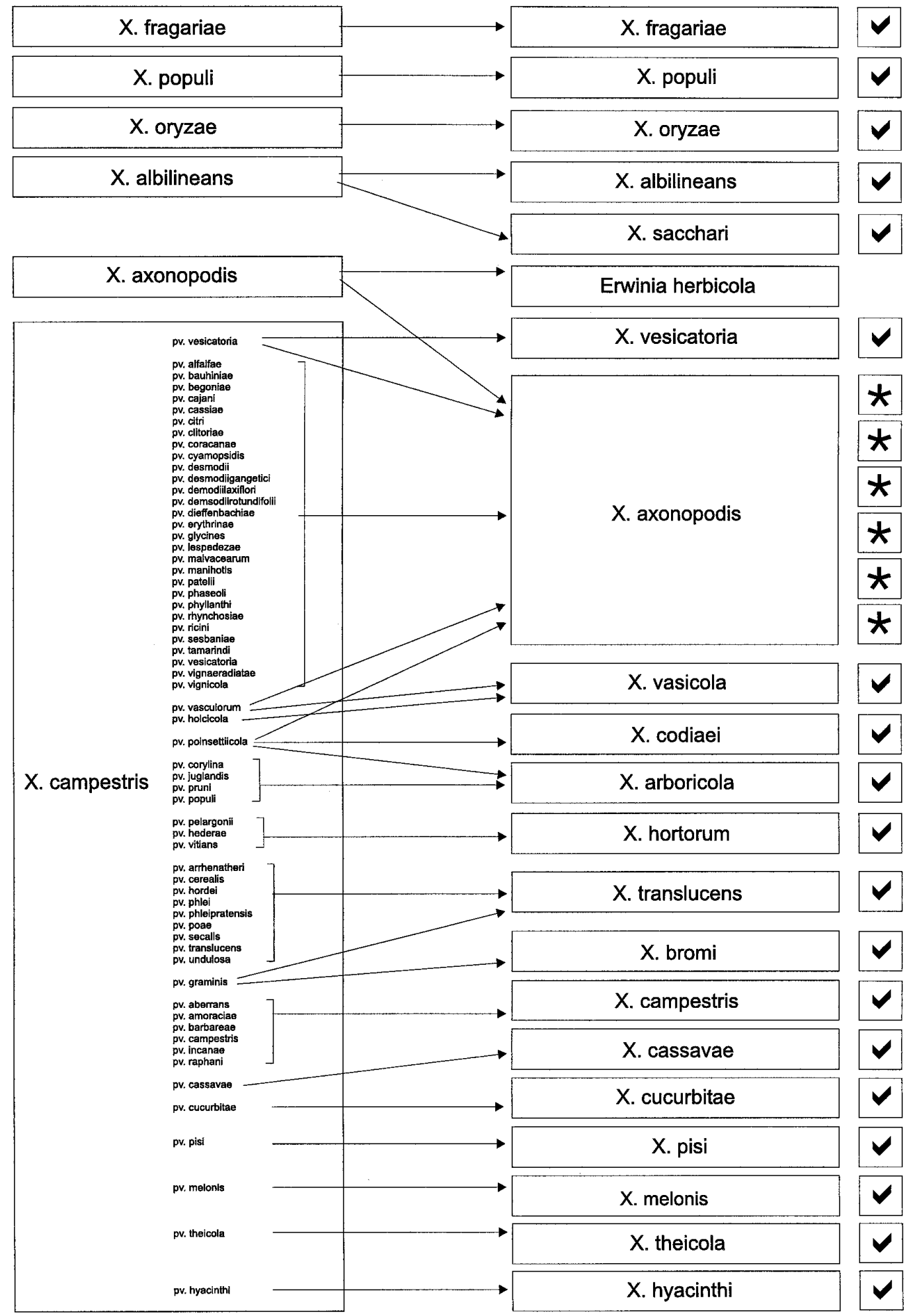

Fig. 1. Schematic representation of the rearrangements proposed within the genus Xanthomonas resulting from a global taxonomic study of more than 1,000 strains and DNA hybridization experiments between 183 selected strains (39) and supported by repetitive sequence-based polymerase chain reaction genomic fingerprinting $(2,21,23,26,28)$. Reclassification according to Vauterin et al. (39). A $\checkmark$ indicates that the species is supported by this genomic fingerprinting technique, whereas a $*$ means that the species is heterogeneous, with the number of groups shown. 
as so-called opportunistic xanthomonads are frequently isolated from plant material. These are xanthomonad populations living in close association with plants but causing no apparent disease symptoms on the host. In the past, this group of nonpathogenic xanthomonads has been largely overlooked, as they were unimportant from an economical point of view in agriculture. However, their existence cannot be neglected. A recent study (45) revealed that the nonpathogenic xanthomonad population was very heterogeneous, containing numerous strains that could not be identified as belonging to one of the existing species.

\section{THE USE OF DNA FINGERPRINTING FOR THE ASSESSMENT OF GENOMIC DIVERSITY}

Assessing the taxonomic diversity and relationships of bacteria requires that large numbers of strains are investigated by measuring their genomic resemblance. DNA hybridization is considered a reliable technique for this purpose, as this technique measures levels of homology between complete genomes. However, a limitation of DNA hybridization methods is that they are not sensitive enough to detect close relationships between strains and populations. A second restriction of DNA hybridization techniques is that they provide pairwise similarities between strains, but no descriptive information about individual strains. Thus, based on DNA hybridization, it is impossible to generate databases with the purpose of identification, as can be done with fingerprints. In other words, this implies that placing an unknown strain into a DNA homology matrix of $n$ strains requires up to $n$ experiments to be carried out. In the example of the genus Xanthomonas, currently consisting of 20 species, identification of an unknown strain would be very laborious based on the DNA homology matrix. A fingerprint, in contrast, once available, can be readily compared with hundreds or thousands of other fingerprints stored in a database by using appropriate computer software. It is believed that the correlation between DNA restriction fragment patterns can be used to estimate genetic distance or relatedness (19), provided that the obtained patterns offer a sufficient number of bands to exceed the statistical and experimental error due to mismatches, misalignments, etc. Janssen et al. (11) conducted a limited study on Xanthomonas species and pathovars using amplified fragment length polymorphism (AFLP), a polymerase chain reaction (PCR)-based fingerprinting technique originally developed in plant breeding (49). AFLP yielded some 30 to 50 PCR products per banding pattern, which is far superior to most other fingerprinting techniques. The groupings of members of the genus Xanthomonas revealed after clustering of AFLP patterns could be nicely correlated with DNA hybridization data obtained previously (39).

Likewise, Louws et al. $(15,16)$ and Schneider and de Bruijn (30) demonstrated that the combined use of PCR fingerprints generated with REP, ERIC, and BOX primers $(4,22,24,25)$ can be used to detect genomic relationships among strains. These studies prove that fingerprint techniques that reveal information about the total genome may become valuable substitutes for DNA hybridization. A series of comprehensive studies $(21,23)$ was conducted using the genus Xanthomonas as a model system comparing the more facile repetitive sequence-based (rep)-PCR and AFLP genomic fingerprinting analyses with DNA hybridization studies. Similarity values derived from rep-PCR- and AFLP-generated fingerprinting analyses were calculated and used to determine the concordance between rep-PCR, AFLP, and DNA hybridization. A high correlation of up to $82 \%$ was observed, suggesting that genomic fingerprinting techniques truly reveal genomic relationships of organisms. Based on these studies, it was proposed that genomic fingerprinting techniques such as rep-PCR and AFLP can be used as rapid, highly discriminatory screening techniques to determine the genomic diversity of bacterial populations $(21,23)$.

Distinct and coherent clusters were observed after computer-assisted pattern analysis of BOX-, ERIC-, and REP-PCR genomic fingerprints that corresponded precisely to those identified by DNA homology studies (DNA homology groups 1 to 8 and 10 to 20 [39]). Within DNA homology group 9 (X. axonopodis), defined by Vauterin et al. (39), six genomic clusters were observed based on rep-PCR fingerprints. A more detailed rep-PCR genomic fingerprinting analysis, using a much larger collection of strains from DNA homology group 9, has been conducted $(21,28)$.

Essentially identical groups were observed using AFLP genomic fingerprint analysis (23). Moreover, clusters found by AFLP analysis belonging to DNA homology group 9 corresponded to those observed by rep-PCR analysis. Additionally, based upon AFLP, a relationship between all of the group 9 strains was observed, but at a relatively low level of similarity. This study and a rep-PCR genomic fingerprinting analysis, based upon a much larger collection of strains $(23,28)$, allowed us to confirm and refine the reclassification of members of the genus Xanthomonas (39), including the observation of several genomic lineages in strains classified within one pathovar.

\section{FUTURE DEVELOPMENTS}

Among the 20 DNA homology groups know so far in the genus Xanthomonas, DNA homology group 9 has the lowest DNA binding value and the highest standard error $(77 \pm 15 \%)$. Since the reclassification as $X$. axonopodis (39), several genomic groups have been found within $X$. axonopodis using AFLP and rep-PCR genomic fingerprinting as presented by J. L. W. Rademaker at the Xanthomonas Workshop at the Seventh International Congress of Plant Pathology in 1988 in Edinburg and at the 1996 and 1997 American Phytopathological Society annual meetings $(17,26,27)$ and by DNA hybridization (12). rep-PCR presumably clarifies the genetic relatedness among the large number of strains currently classified within the species. $X$. axonopodis could be divided in up to six separate clusters based on rep-PCR fingerprints, depending on the defined threshold. In this case, however, it is justified to say that further work is needed to confirm the subgroups found before further nomenclatural changes can be proposed.

We regret that 4 years after the reclassification of the genus Xanthomonas (39), the Letter to the Editor by Schaad et al. (29) presents neither additional research data nor valid scientific or nomenclatural arguments that conflict with the species subdivision proposed by Vauterin et al. (39). Instead, all recent genomic studies performed on large collections of strains do support the groupings found $(17,21-23,26,28)$. Rejection of functional species that are validly published and based upon scientific grounds, as proposed by Schaad et al. (29), is nothing less than ignoring more than 10 years of scientific research conducted in several laboratories, based upon a few alleged facts. Such a rejection would create more confusion than the introduction of the new names has ever caused and would be misleading for the microbiological and phytopathological community. Nomenclature is an important step in taxonomic progress, particularly when this activity is viewed as a synthesis of the actual biological knowledge of a taxon. Nomenclatural changes are justified only in the cases in which strong new evidence is produced. Vauterin et al.'s (39) proposal took into account both concerns. Hence, there is no need for retrogressive actions such as the ones proposed by Schaad et al. (29), as this not only would restrain scientific progress and hamper practical implementation of nomenclature, but also would prepare for undesirable and unnecessary future nomenclatural changes.

We recognize that scientists should not close their eyes for possible effects of renaming bacteria; however, apparent short-term drawbacks should not inhibit the progress of taxonomy as a scientific discipline. If the classification of bacteria is not to be based on scientific research data, the characteristics of the defined taxa and their consequences for human being, e.g., in the case of pathogens, will never be well understood. The pv. citri story (34) illustrates the serious economic consequences caused by incorrect as- 
sessment of relationships between pathovars and belated renaming of the pathogens. Therefore, a proper classification, reflecting the existing natural diversity and relationships, is indispensable for all parties. Plant breeders and growers as well as legislators need a proper classification to ensure effective disease diagnosis and management and to avoid unnecessary destruction of economically valuable crops. To plant breeders, knowledge of the genomic diversity within pathovars is essential for the development of host resistancebased disease management strategies.

As a concluding remark, we would like to stress that we applaud further developments in the classification of the genus Xanthomonas as well as in other problematic bacterial genera. It is our belief, however, that any future progress in taxonomy as a scientific discipline will depend only on the availability of new experimental data that will allow us both to broaden and to refine our view on bacterial diversity.

\section{LITERATURE CITED}

1. Bradbury, J. F. 1986. Xanthomonas Dowson 1939, 187. Pages 198-260 in: Guide to Plant Pathogenic Bacteria. CAB International Mycological Institute, Slough, England.

2. Bragard, C., Singer, E., Alizadeh, A., Vauterin, L., Maraite, H., and Swings, J. 1997. Xanthomonas translucens from small grains: Diversity and phytopathological relevance. Phytopathology 87:1111-1117.

3. Burkholder, W. H., and Starr, M. P. 1948. The generic and specific characters of phytopathogenic species of Pseudomonas and Xanthomonas. Phytopathology 38:494-502.

4. de Bruijn, F. J. 1992. Use of repetitive (repetitive extragenic palindromic and enterobacterial repetitive intergenic consensus) sequences and the polymerase chain reaction to fingerprint the genomes of Rhizobium meliloti isolates and other soil bacteria. Appl. Environ. Microbiol. 58: 2180-2187.

5. Dye, D. W. 1962. The inadequacy of the usual determinative tests for the identification of Xanthomonas spp. N.Z. J. Sci. 5:393-416.

6. Dye, D. W., and Lelliott, R. A. 1974. Genus II. Xanthomonas. Pages 243-249 in: Bergey's Manual of Determinative Bacteriology, 8th ed. R. E. Buchanan and N. E. Gibbons, eds. Williams \& Wilkins, Baltimore.

7. Hauben, L., Vauterin, L., Swings, J., and Moore, E. R. B. 1997. Comparison of 16S ribosomal DNA sequences of all Xanthomonas species. Int. J. Syst. Bacteriol. 47:328-335.

8. Hayward, A. C. 1993. The hosts of Xanthomonas. Pages 1-119 in: Xanthomonas. J. G. Swings and E. L. Civerolo, eds. Chapman \& Hall, London.

9. Hildebrand, D. C., Hendson, M., and Schroth, M. N. 1993. Usefulness of nutritional screening for the identification of Xanthomonas campestris DNA homology groups and pathovars. J. Appl. Bacteriol. 75:447-455.

10. Hildebrand, D. C., Palleroni, N. J., and Schroth, M. N. 1990. Deoxyribonucleic acid relatedness of 24 xanthomonad strains representing 23 Xanthomonas campestris pathovars and Xanthomonas fragariae. J. Appl. Bacteriol. 68:263-269.

11. Janssen, P., Coopman, R., Huys, G., Swings, J., Bleeker, M., Vos, P., Zabeau, M., and Kersters, K. 1996. Evaluation of the DNA fingerprinting method AFLP as a new tool in bacterial taxonomy. Microbiology 142:1881-1893.

12. Lacy, G. H., Gherna, R. L., Stromberg, V. K., Toth, J., Cote, R., and Johnson, J. L. 1997. DNA homology groups among 122 ATCC xanthomonad strains. (Abstr.) Phytopathology 87(suppl.):S55.

13. Lapage, S. P., Sneath, P. H. A., Lessel, E. F., Skerman, V. B. D., Seeliger, H. P. R., and Clark, W. A. 1992. International Code of Nomenclature of Bacteria (1990 Revision). American Society for Microbiology, Washington, DC.

14. Lee, Y.-A., Hildebrand, D. C., and Schroth, M. N. 1992. Use of quinate metabolism as a phenotypic property to identify members of Xanthomonas campestris DNA homology group 6. Phytopathology 82:971-973.

15. Louws, F. J., Fulbright, D. W., Taylor Stephens, C., and de Bruijn, F. J. 1994. Specific genomic fingerprints of phytopathogenic Xanthomonas and Pseudomonas pathovars and strains generated with repetitive sequences and PCR. Appl. Environ. Microbiol. 60:2286-2295.

16. Louws, F. J., Fulbright, D. W., Taylor Stephens, C., and de Bruijn, F. J. 1995. Differentiation of genomic structure by rep-PCR fingerprinting to rapidly classify Xanthomonas campestris pv. vesicatoria. Phytopathology 85:528-536.

17. Louws, F. J., Rademaker, J. L. W., Stromberg, V. K., Gherna, R. L., de Bruijn, F. J., and Lacy, G. H. 1997. Rep-PCR genomic fingerprinting of 123 ATCC xanthomonad strains. (Abstr.) Phytopathology 87(suppl.):S60.

18. Murata, G. R., and Starr, M. P. 1973. A concept of the genus Xanthomonas and its species in the light of segmental homology of deoxyribo- nucleic acids. Phytopathol. Z. 77:285-323.

19. Nei, M., and Li, W.-H. 1979. Mathematical model for studying genetic variations in terms of restriction endonucleases. Proc. Natl. Acad. Sci. U.S.A. 76:5269-5273.

20. Palleroni, N. J., Hildebrand, D. C., Schroth, M. N., and Hendson, M. 1993. Deoxyribonucleic acid relatedness of 21 strains of Xanthomonas species and pathovars. J. Appl. Bacteriol. 75:441-446.

21. Rademaker, J. L. W. 1999. Computer-assisted pattern analysis of repPCR genomic fingerprints in the molecular systematics of Xanthomonas. Ph.D. thesis. Universiteit Gent, Gent, Belgium.

22. Rademaker, J. L. W., and de Bruijn, F. J. 1997. Characterization and classification of microbes by rep-PCR genomic fingerprinting and computer-assisted pattern analysis. Pages 151-171 in: DNA Markers, Protocols, Applications and Overviews, Chapter 10. G. Ceatano-Anollés and P. M. Gresshoff, eds. J. Wiley \& Sons, New York.

23. Rademaker, J. L. W., Hoste, B., Louws, F. J., Kersters, K., Swings, J., Vauterin, L., Vauterin, P., and de Bruijn, F. J. 2000. Comparison of AFLP and rep-PCR genomic fingerprinting with DNA-DNA homology studies: Xanthomonas as a model system. Int. J. Syst. Evol. Microbiol. 50:665-677.

24. Rademaker, J. L. W., Louws, F. J., and de Bruijn, F. J. 1998. Characterization of the diversity of ecologically important microbes by rep-PCR genomic fingerprinting. Pages 1-26 in: Molecular Microbial Ecology Manual, Supplement 3, Chapter 3.4.3 . A. D. L. Akkermans, J. D. van Elsas, and F. J. de Bruijn, eds. Kluwer Academic Publishers, Dordrecht, the Netherlands.

25. Rademaker, J. L. W., Louws, F. J., Rossbach, U., Vinuesa, P., and de Bruijn, F. J. 1999 Computer-assisted pattern analysis of molecular fingerprints and database construction. Pages 1-33 in: Molecular Microbial Ecology Manual, Supplement 4, Chapter 7.3.1. A. D. L. Akkermans, J. D. van Elsas, and F. J. de Bruijn, eds. Kluwer Academic Publishers, Dordrecht, the Netherlands.

26. Rademaker, J. L. W., Louws, F. J., Schultz, M. H., Rossbach, U., Vauterin, L., Swings, J., and de Bruijn, F. J. 1997. Molecular systematics of xanthomonads by rep-PCR genomic fingerprinting and computer-assisted pattern analysis. (Abstr.) Phytopathology 87(suppl.):S81.

27. Rademaker, J. L. W., Louws, F. J., Tuang, F. N., Schultz, M. H., Rossbach, U., Vauterin, L., Swings, J., Alocilja, E., and de Bruijn, F. J. 1997. Computer-assisted "on line" identification of xanthomonads by a rep-PCR database or artificial neural network. (Abstr.) Phytopathology 87(suppl.):S81.

28. Rademaker, J. L. W., Louws, F. J., Schultz, M. H., Rossbach, U., Vauterin, L., Swings, J., and de Bruijn, F. J. 1999. Molecular systematics of xanthomonads by rep-PCR genomic fingerprinting and computer-assisted pattern analysis. Chapter 3.2 in: Computer-assisted pattern analysis of rep-PCR genomic fingerprints in the molecular systematics of Xanthomonas. Ph.D. thesis. Universiteit Gent, Gent, Belgium.

29. Schaad, N. W., Vidaver, A. K., Lacy, G. H., Rudolph, K., and Jones, J. B. 2000. Evaluation of proposed amended names of several pseudomonads and xanthomonads and recommendations. Phytopathology 90:208-213.

30. Schneider, M., and de Bruijn, F. J. 1996. Rep-PCR mediated genomic fingerprinting of rhizobia and computer-assisted phylogenetic pattern analysis. World J. Microbiol. Biotechnol. 12:163-174.

31. Schroth, M. N., and Hildebrand, D. C. 1983. Toward a sensible taxonomy of bacterial plant pathogens. Plant Dis. 67:128.

32. Skerman, V. B. D., McGowan, V., and Sneath, P. H. A. 1980. Approved Lists of Bacterial Names. Int. J. Syst. Bacteriol. 30:225-420.

33. Stall, R. E., Beaulieu, C., Egel, D., Hodge, N. C., Leite, R. P., Minsavage, G. V., Bouzar, H., Jones, J. B., Alvarez, A. M., and Benedict, A. A. 1991. Two genetically diverse groups of strains are included in Xanthomonas campestris pv. vesicatoria. Int. J. Syst. Bacteriol. 44:47-53.

34. Stall, R. E., and Civerolo, E. L. 1994. Research relating to the recent outbreak of citrus canker in Florida. Annu. Rev. Phytopathol. 29:399-420.

35. Starr, M. P. 1981. The genus Xanthomonas. Pages 742-763 in: The Prokaryotes. M. P. Starr, H. Stolp, H. G. Trüper, A. Balows, and H. G. Schlegel, eds. Springer Verlag, Berlin.

36. Stead, D. 1989. Grouping of Xanthomonas campestris pathovars of cereals and grasses by fatty acid profiling. Bull. OEPP (Organ. Eur. Mediterr. Prot. Plant.) 19:57-68.

37. Van den Mooter, M., Maraite, H., Meiresonne, L., Swings, J., Gillis, M., Kersters, K., and De Ley, J. 1987. Comparison between Xanthomonas campestris pv. manihotis (ISPP List 1980) and X. campestris pv. cassavae (ISPP List 1980) by means of phenotypic, protein electrophoretic, DNA hybridization and phytopathological techniques. J. Gen. Microbiol. 133:57-71.

38. Van den Mooter, M., and Swings, J. 1990. Numerical analysis of 295 phenotypic features of 266 Xanthomonas strains and related strains and an improved taxonomy of the genus. Int. J. Syst. Bacteriol. 40:348-369.

39. Vauterin, L., Hoste, B., Kersters, K., and Swings, J. 1995. Reclassification of Xanthomonas. Int. J. Syst. Bacteriol. 45:472-489.

40. Vauterin, L., Hoste, B., Yang, P., Alvarez, A., Kersters, K., and Swings, J. 1993. Taxonomy of the genus Xanthomonas. Pages 157-192 in: Xanthomonas. J. G. Swings and E. L. Civerolo, eds. Chapman \& Hall, London. 
41. Vauterin, L., Swings, J., and Kersters, K. 1991. Grouping of Xanthomonas campestris pathovars by SDS-PAGE of proteins. J. Gen. Microbiol. 137:1677-1687.

42. Vauterin, L., Swings, J., and Kersters, K. 1993. Protein electrophoresis and classification. Pages 251-280 in: Handbook of New Bacterial Systematics. M. Goodfellow and M. G. O'Donnell, eds. Academic Press, London.

43. Vauterin, L., Swings, J., Kersters, K., Gillis, M., Mew, T. W., Schroth, M. N., Palleroni, N. J., Hildebrand, D. C., Stead, D. E., Civerolo, E. L., Hayward, A. C., Maraite, H., Stall, R. E., Vidaver, A. K., and Bradbury, J. F. 1990. Towards an improved taxonomy of Xanthomonas. Int. J. Syst. Bacteriol. 40:312-316.

44. Vauterin, L., Vantomme, R., Pot, B., Hoste, B., Swings, J., and Kersters, K. 1990. Taxonomic analysis of Xanthomonas campestris pv. begoniae and $X$. campestris pv. pelargonii by means of phytopathological, phenotypic, protein electrophoretic and DNA hybridization methods. Syst. Appl. Microbiol. 13:166-176.

45. Vauterin, L., Yang, P., Alvarez, A., Takikawa, Y., Roth, D. A., Vidaver, A. K., Stall, R. E., Kersters, K., and Swings, J. 1996. Identification of non-pathogenic Xanthomonas strains associated with plants. Syst. Appl. Microbiol. 19:96-105.
46. Vauterin, L., Yang, P., Hoste, B., Pot, B., Swings, J., and Kersters, K. 1992. Taxonomy of xanthomonads from cereals and grasses based on SDS-PAGE of proteins, fatty acid analysis and DNA hybridization. J. Gen. Microbiol. 138:1467-1477.

47. Vauterin, L., Yang, P., Hoste, B., Vancanneyt, M., Civerolo, E. L., Swings, J., and Kersters, K. 1991. Differentiation of Xanthomonas campestris pv. citri strains by sodium dodecyl sulfate-polyacrylamide gel electrophoresis of proteins, fatty acid analysis, and DNA hybridization. Int. J. Syst. Bacteriol. 41:535-542.

48. Vauterin, L., Yang, P., and Swings, J. 1996. Utilization of fatty acid methyl esters for the differentiation of new Xanthomonas species. Int. J. Syst. Bacteriol. 46:298-304.

49. Vos, P., Hogers, R., Bleeker, M., Rijans, M., van de Lee, T., Hornes, M., Freijters, A., Pot, J., Peleman, J., Kuiper, M., and Zabeau, M. 1995. AFLP: A new concept for DNA fingerprinting. Nucleic Acids Res. 21:4407-4414.

50. Yang, P., Vauterin, L., Vancanneyt, M., Swings, J., and Kersters, K. 1993. Application of fatty acid methyl esters for the taxonomic analysis of the genus Xanthomonas. Syst. Appl. Microbiol. 16:47-71.

51. Young, J. M., Dye, D. W., Bradbury, J. F., Panagopoulos, C. G., and Robbs, C. F. 1978. A proposed nomenclature and classification for plant pathogenic bacteria. N.Z. J. Agric. Res. 21:153-177. 